\title{
The Chaitén rhyolite lava dome: Eruption sequence, lava dome volumes, rapid effusion rates and source of the rhyolite magma
}

\author{
*John S. Pallister¹, Angela K. Diefenbach¹, William C. Burton², Jorge Muñoz ${ }^{3}$, Julia P. Griswold', \\ Luis E. Lara ${ }^{3}$, Jacob B. Lowenstern ${ }^{4}$, Carolina E. Valenzuela ${ }^{3}$
}

\author{
${ }^{\prime}$ United States Geological Survey, Cascades Volcano Observatory, 1300 SE Cardinal Court, Vancouver, WA 98683, USA. \\ jpallist@usgs.gov; adiefenbach@usgs.gov; griswold@usgs.gov \\ ${ }^{2}$ United States Geological Survey, 12201 Sunrise Valley Drive, Reston VA 20192, USA. \\ bburton@usgs.gov \\ ${ }^{3}$ Servicio Nacional de Geología y Minería, Avda. Santa María 0104, Santiago, Chile. \\ jorge.munoz@sernageomin.cl; luis.lara@sernageomin.cl; carovale@gmail.com \\ ${ }^{4}$ United States Geological Survey, 345 Middlefield Road, Menlo Park, CA 94025, USA. \\ jlwnstrn@usgs.gov \\ *Corresponding author: jpallist@usgs.gov
}

\begin{abstract}
We use geologic field mapping and sampling, photogrammetric analysis of oblique aerial photographs, and digital elevation models to document the 2008-2009 eruptive sequence at Chaitén Volcano and to estimate volumes and effusion rates for the lava dome. We also present geochemical and petrologic data that contribute to understanding the source of the rhyolite and its unusually rapid effusion rates. The eruption consisted of five major phases: $\mathbf{1}$. An explosive phase (1-11 May 2008); 2. A transitional phase (11-31 May 2008) in which low-altitude tephra columns and simultaneous lava extrusion took place; 3. An exogenous lava flow phase (June-September 2008); 4. A spine extrusion and endogenous growth phase (October 2008-February 2009); and 5. A mainly endogenous growth phase that began after the collapse of a prominent Peléean spine on 19 February 2009 and continued until the end of the eruption (late 2009 or possibly earliest 2010). The 2008-2009 rhyolite lava dome has a total volume of approximately $0.8 \mathrm{~km}^{3}$. The effusion rate averaged $66 \mathrm{~m}^{3} \mathrm{~s}^{-1}$ during the first two weeks and averaged $45 \mathrm{~m}^{3} \mathrm{~s}^{-1}$ for the first four months of the eruption, during which $0.5 \mathrm{~km}^{3}$ of rhyolite lava was erupted. These are among the highest rates measured world-wide for historical eruptions of silicic lava. Chaitén's 2008-2009 lava is phenocryst-poor obsidian and microcrystalline rhyolite with $75.3 \pm 0.3 \% \mathrm{SiO}_{2}$. The lava was erupted at relatively high temperature and is remarkably similar in composition and petrography to Chaitén's pre-historic rhyolite. The rhyolite's normative composition plots close to that of low pressure (100-200 MPa) minimum melts in the granite system, consistent with estimates of approximately 5 to $10 \mathrm{~km}$ source depths based on phase equilibria and geodetic studies. Calcic plagioclase, magnesian orthopyroxene and aluminous amphibole among the sparse phenocrysts suggest derivation of the rhyolite by melt extraction from a more mafic magmatic mush. High temperature and relatively low viscosity enabled rapid magma ascent and high effusion rates during the dome-forming phases of the 2008-2009 eruption.
\end{abstract}


RESUMEN. El domo riolítico del volcán Chaitén: secuencia eruptiva, tasa de emisión y fuente del magma riolítico. Mediante mapeo geológico y muestreo, análisis fotogramétrico de fotografías aéreas oblicuas y modelos de elevación digital, se documenta la secuencia eruptiva 2008-2009 del volcán Chaitén para estimar el volumen y la tasa de emisión del domo. Además, se presentan datos geoquímicos y petrológicos que contribuyen a la comprensión de la fuente de este magma riolítico y su inusualmente alta tasa de emisión. La erupción consistió en cinco fases mayores: 1. Fase explosiva (1-11 mayo, 2008), 2. Fase transicional (11-31 mayo, 2008), 3. Fase de crecimiento exógeno (junioseptiembre, 2008), 4. Fase de extrusión de la espina y crecimiento endógeno (octubre 2008 a febrero 2009), y 5. Fase de crecimiento principalmente endógeno, esta última iniciada a continuación del colapso de la prominente espina, el 19 de febrero de 2009, y seguida hasta el final de la erupción (fin de 2009 o posiblemente inicio de 2010). El domo riolítico 2008-2009 tiene un volumen total de aproximadamente $0,8 \mathrm{~km}^{3}$. La tasa de emisión promedió $66 \mathrm{~m}^{3} / \mathrm{seg}$ durante las dos primeras semanas y $45 \mathrm{~m}^{3} / \mathrm{seg}$ los primeros cuatro meses de erupción, durante los cuales fueron eruptadas $0,5 \mathrm{~km}^{3}$ de lava riolítica. Estos valores están entre los más altos registrados en el mundo para erupciones históricas de magma silíceo. La lava 2008-2009 del volcán Chaitén varía desde una obsidiana pobre en cristales a una riolita microcristalina con $75,3 \pm 0,3 \% \mathrm{SiO}_{2}$. Esta lava fue evacuada a temperatura relativamente alta y es notablemente similar composicional y petrográficamente a las riolitas prehistóricas de este volcán. La composición normativa de la riolita corresponde a aquella de los fundidos de baja presión (100-200 MPa) en el sistema del granito, consistente con profundidades estimadas de 5 a $10 \mathrm{~km}$ obtenidas a partir de equilibrio de fases y modelos geodésicos. Entre los escasos fenocristales, la plagioclasa cálcica, el ortopiroxeno magnésico y la anfíbola aluminosa sugieren que la riolita deriva de un ensamblaje más máfico. La alta temperatura y una viscosidad relativamente baja, permitieron el rápido ascenso del magma y las altas tasas de emisión durante las fases de construcción del domo 2008-2009.

Palabras clave: Volcanología, Riolita, Caldera, Lava domo, Tasa de emisión, Fotogrametría, Geoquímica, Chaitén.

\section{Introduction}

High-silica rhyolite magma fuels Earth's largest and most explosive eruptions, which are typically associated with collapse calderas, have peak eruption rates of $10^{9}$ to $10^{10} \mathrm{~kg} \mathrm{~s}^{-1}\left(\sim 10^{5}\right.$ to $\left.10^{6} \mathrm{~m}^{3} \mathrm{~s}^{-1}\right)$, volumes of $\sim 10^{1}$ $10^{3} \mathrm{~km}^{3}$ and recurrence intervals that range from $10^{2}$ to $10^{6} \mathrm{y}$ (Pyle, 2000; Mason et al., 2004; Self, 2006). However, there have been few direct observations of such explosive and large-volume rhyolite eruptions, e.g., those with Volcanic Explosivity Indices (VEI, Newhall and Self, 1982) $\geq 4$. Consequently, there was keen interest within the volcanology community when an explosive eruption began in early May 2008 at Chaitén Volcano, Chile (Fig. 1), the first large eruption of high-silica rhyolite at a caldera since that of Alaska's Katmai-Novarupta caldera system in 1912 (Muñoz et al., 2008; 2009a; Carn et al., 2009; Castro and Dingwell, 2009; Lara, 2009).

Prior to 2008, Chaitén caldera was considered an inactive volcano, consisting of a circular $2.5 \mathrm{~km}$ diameter collapse caldera containing a pre-historic intracaldera lava dome surrounded by a circular moat. Formation of the caldera and associated eruption of rhyolite tephra took place between 9,000 and 10,000 years ago (Naranjo and Stern, 2004; Lara et al.,
2013, this volume; Watt et al., 2013, this volume). The pre-historic lava dome is composed of high-silica rhyolite (obsidian and variably devitrified rhyolite lava). Obsidian pebbles from an archeological site dated at $\sim 5,600$ radiocarbon years are attributed to the lava dome (Stern et al., 2002). However, other deposits on the flanks of the caldera are dated at $\leq 3 \mathrm{ka}$ (Lara et al., 2013, this volume; Watt et al., 2013, this volume) and contain rhyolite that is geochemically similar to that of the lava dome. Consequently, the exact age of the last eruption of rhyolite at Chaitén prior to 2008 is uncertain, but may have been historical (Lara et al., 2013, this volume).

Overviews of the 2008-2009 ${ }^{1}$ eruption and its impacts are given in Carn et al. (2009), Muñoz et al. (2009b), Lara (2009) and Major and Lara (2013, this volume). Petrologic and geodetic data that constrain the initial ascent rate and pathway for the rhyolite magma are presented in Castro and Dingwell (2009) and Wicks et al. (2011). Halogen geochemistry and partitioning of elements during late degassing are given by Lowenstern et al. (2012), and tephra distribution from the 2008 eruptions is described by Watt et al. (2009) and Alfano et al. (2011). Additional information on the eruption, its deposits and impacts is presented in this issue of Andean Geology. 


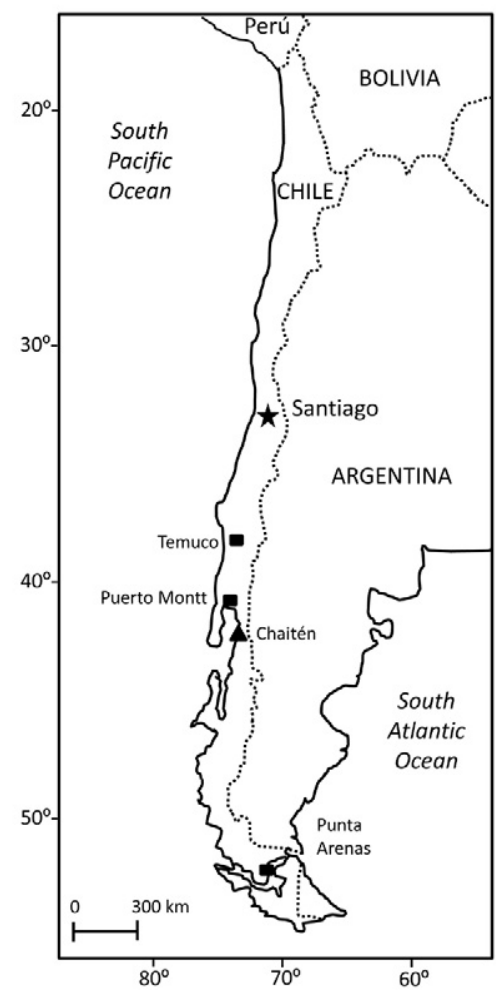

FIG. 1. Index map showing location of Chaitén caldera.

Numerous studies have been conducted on the deposits from pre-historic rhyolite caldera eruptions, and because of their large volumes and modeled highaltitude eruptive columns, the mass flow rates for the explosive phases of these eruptions must have been enormous (Carey and Sigurdsson, 1989). But what were the effusion rates for the high-silica rhyolite lava-dome-forming eruptions, which typically follow the explosive phases at these volcanoes? Because of their high silica contents (and presumed high viscosities) it is sometimes assumed that effusion rates for these rhyolite lavas were relatively low. But what does the prolonged eruption of rhyolite during 2008-2009 at Chaitén tell us? This is the main question addressed by our work. We use data derived from aerial photographs, satellite images, and ground-based observations to define the eruptive sequence, map the growth of the lava dome, and to calculate eruptive volumes and effusion rates for lava. We also summarize the geochemistry and petrography of the magma and we conclude with a hypothesis to explain unusually high eruption rates that we determine for the rhyolite lava. Additional details of lava dome growth at Chaitén, including complementary thermal data from Forward Looking Infrared Radiometer (FLIR) images are reported by Bernstein et al. (2013, this volume).

\section{Methods}

\subsection{Photogeology and Geographic Information System (GIS) analysis}

We used a combination of oblique photographs from aircraft (Figs. 2 and 3), helicopter-assisted fieldwork by an international team in 2010 (Pallister $e t$ al., 2010) and commercial satellite imagery (Fig. 4) to map the development of the Chaitén lava dome during the 2008-2009 eruptive sequence (Fig. 5). Volumes of dome lobes were estimated during the first 4 months of the eruption while their geometries were relatively simple. We calculated areas and thicknesses of the dome lobes by a combination of visual inspection of aerial photos (Fig. 6) and GIS analysis of georectified satellite images (e.g., Fig. 4). Volumes were then calculated using the most appropriate geometries (e.g., $1 / 2$ hemispheres, or width multiplied by length and height for approximately rectangular solids).

In addition, the total 2008-2009 dome volume was calculated by differencing post- and pre-eruption Digital Elevation Models (DEMs) (Fig. 7). Three pre-eruption DEMs were constructed using: 1. The 1:50,000-scale Chaitén topographic map (Sheet 42457230 of the Instituto Geográfico Militar de Chile, 1997 edition); 2. Advanced Spaceborne Thermal Emission and Reflection Radiometer (ASTER) images; and 3. Shuttle Radar Topography Mission (SRTM) images. Two post-eruption DEMs were constructed using data from: 1. An airborne LIDAR survey conducted by Digimapas Chile between 15 October and 7 December 2009 and provided by the Regional Government of Los Lagos region and 2. Overlapping digital oblique photographs using the photogrammetric method of Diefenbach et al. (2012). The oblique aerial photographs were shot from a helicopter by the first author on 24 January 2010 using a digital single-lens reflex camera, while circling the caldera rim at 1,530 $\mathrm{m}$ and 2,740 $\mathrm{m}$ elevations. Control points for the oblique photographs were established using benchmarks from the topographic map and by using a combination of GPS locations and altimeter readings. A boundary shapefile ('cookie cutter', Fig. 7) of the area of dome growth was used to clip each of the 
three pre-eruption DEMs ('Base surface', Fig. 7) and the two new lava dome DEMs ('New surface', Fig. 7). The elevation difference ('difference map', Fig. 7) between corresponding cells yielded an estimate of the total volume of extruded lava. Each of the resulting six differencing iterations gave similar results (within $\pm 10 \%$ ); however, owing to radar shadows in the SRTM DEM and the low spatial resolution of the ASTER DEM, we regard the most reliable volumes as those derived by differencing the 1997 topographic map DEM and either the photogrammetric oblique photo DEM or the LIDAR DEM.
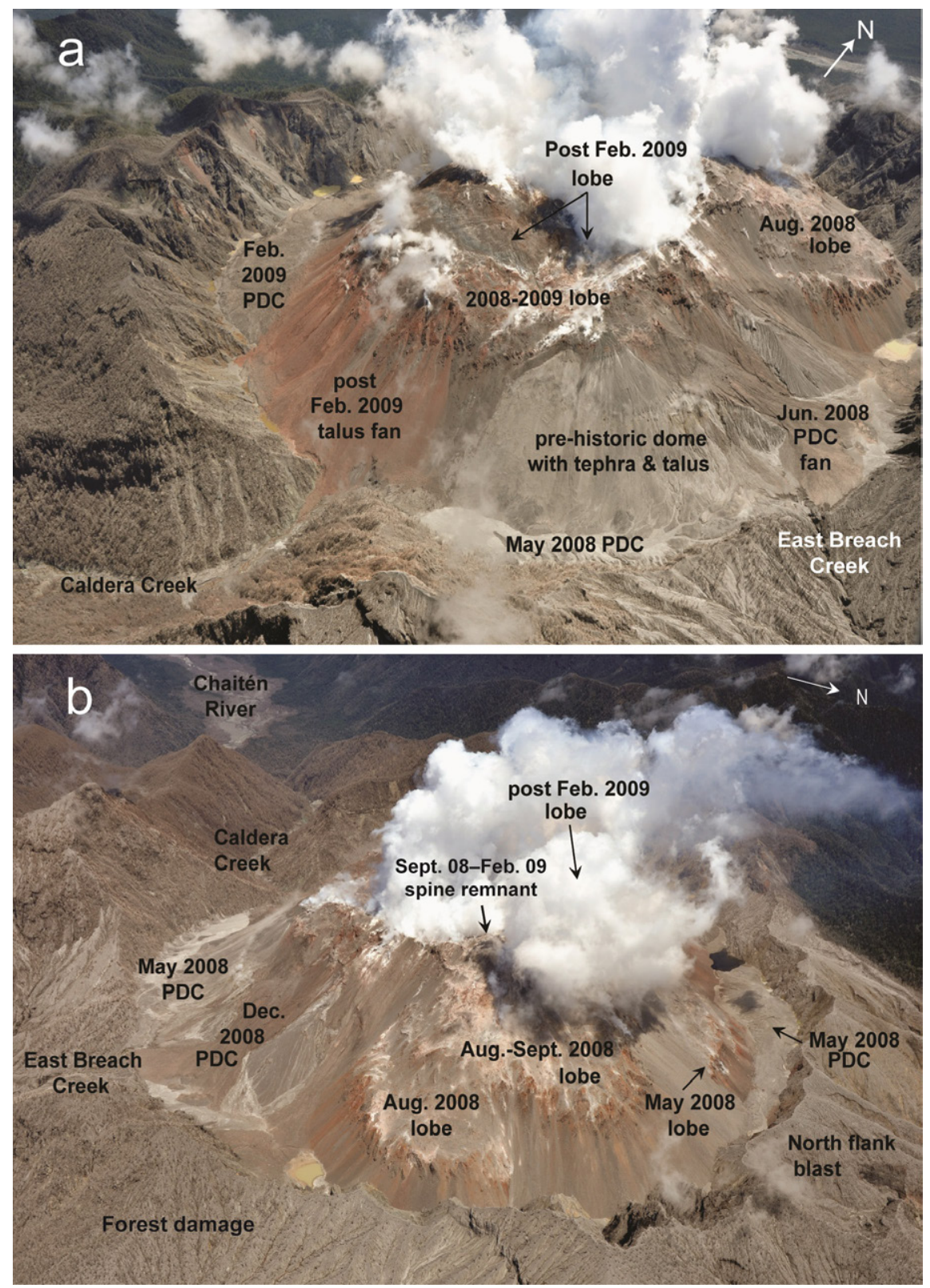

FIG. 2. a. Oblique aerial photographs of Chaitén caldera taken on 24 January 2010; view to northwest; b. Labels indicate prominent dome lobes, pyroclastic density current deposits, talus fans and areas of forest damage, view to southwest. Diameter of caldera moat (as seen in this and subsequent images) is approximately $2.5 \mathrm{~km}$. See geologic map (Fig. 5) for reference. 

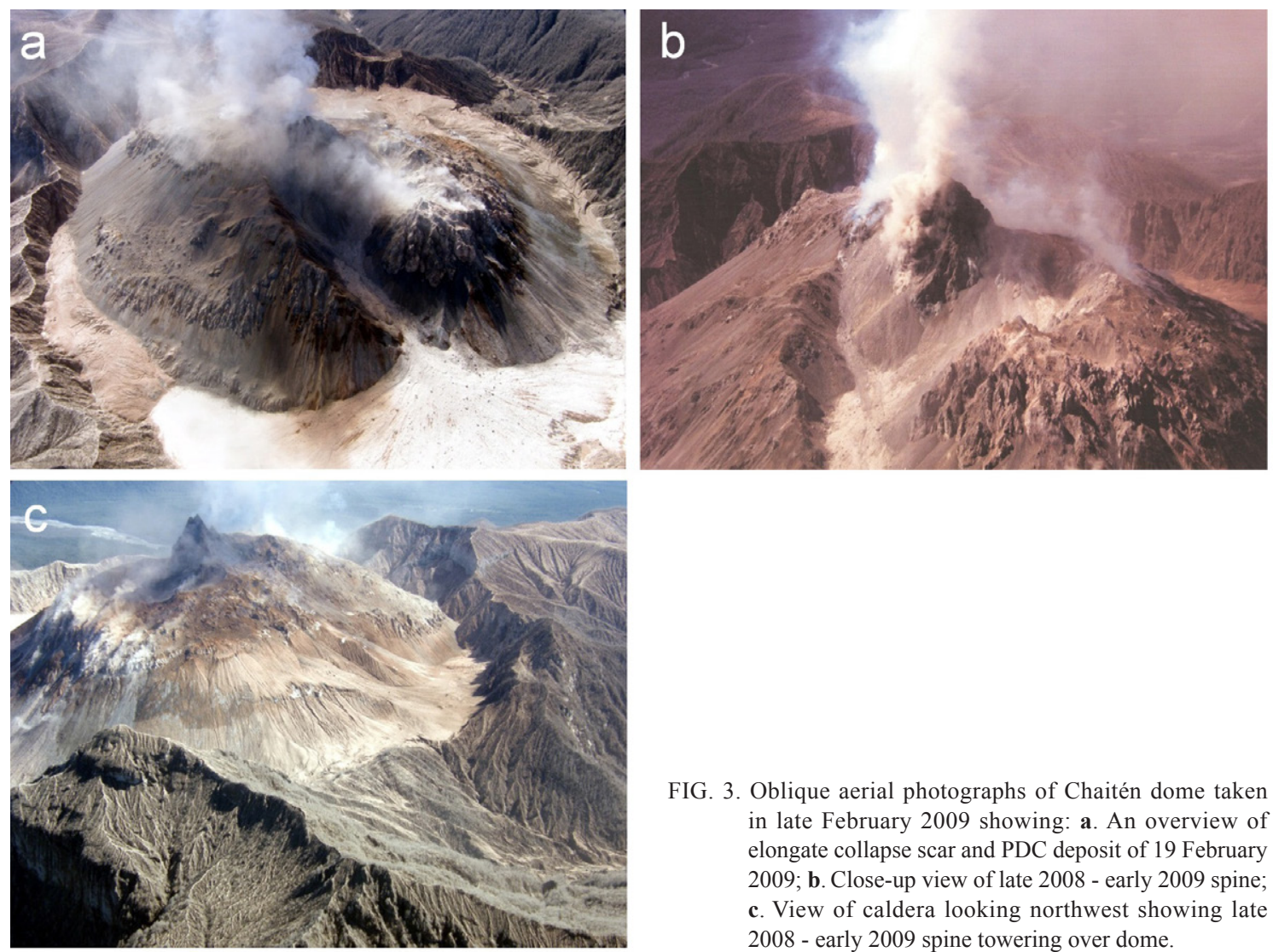

FIG. 3. Oblique aerial photographs of Chaitén dome taken in late February 2009 showing: a. An overview of elongate collapse scar and PDC deposit of 19 February 2009; b. Close-up view of late 2008 - early 2009 spine; c. View of caldera looking northwest showing late 2008 - early 2009 spine towering over dome.

FIG. 4. Worldview image (reproduced with permission of Digital Globe $^{\circledR}$ ) of Chaitén caldera on 3 January 2009. Image shows prominent dome lobes and areas of most severe forest damage (mainly blow-down and some areas of standing-dead trees north and east of the caldera shown by dot-dash line).

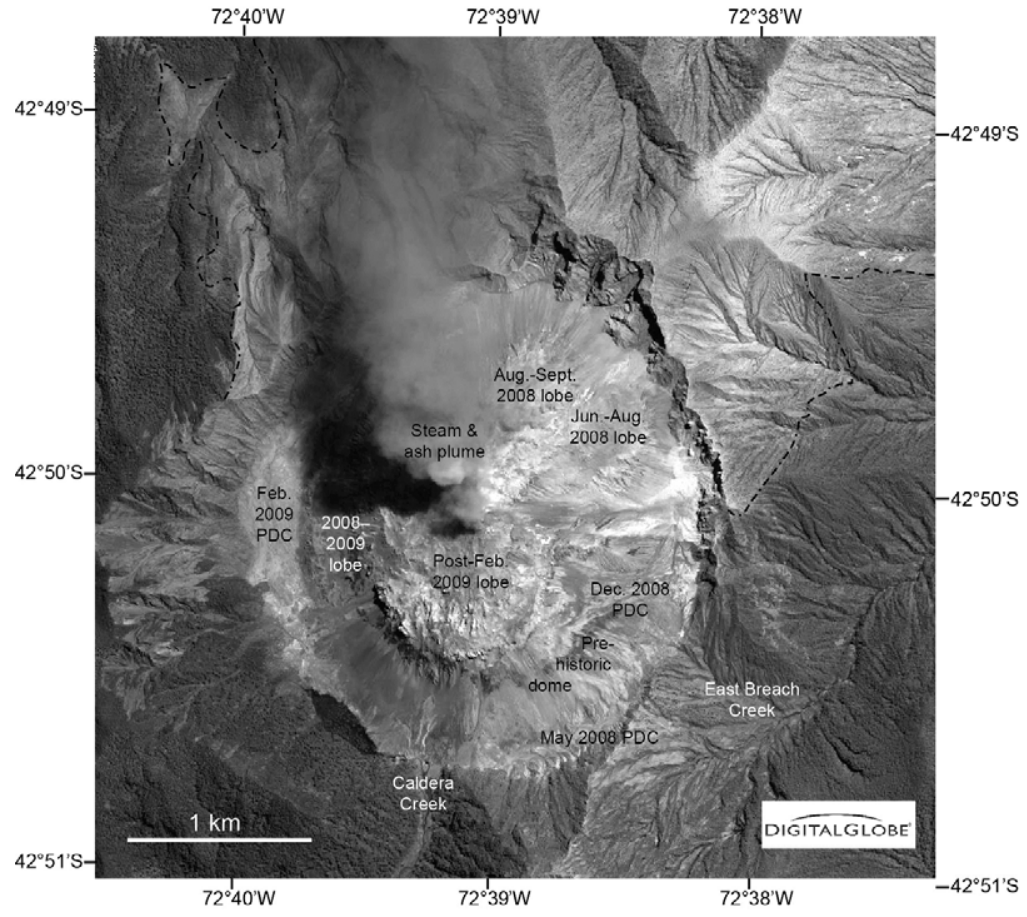




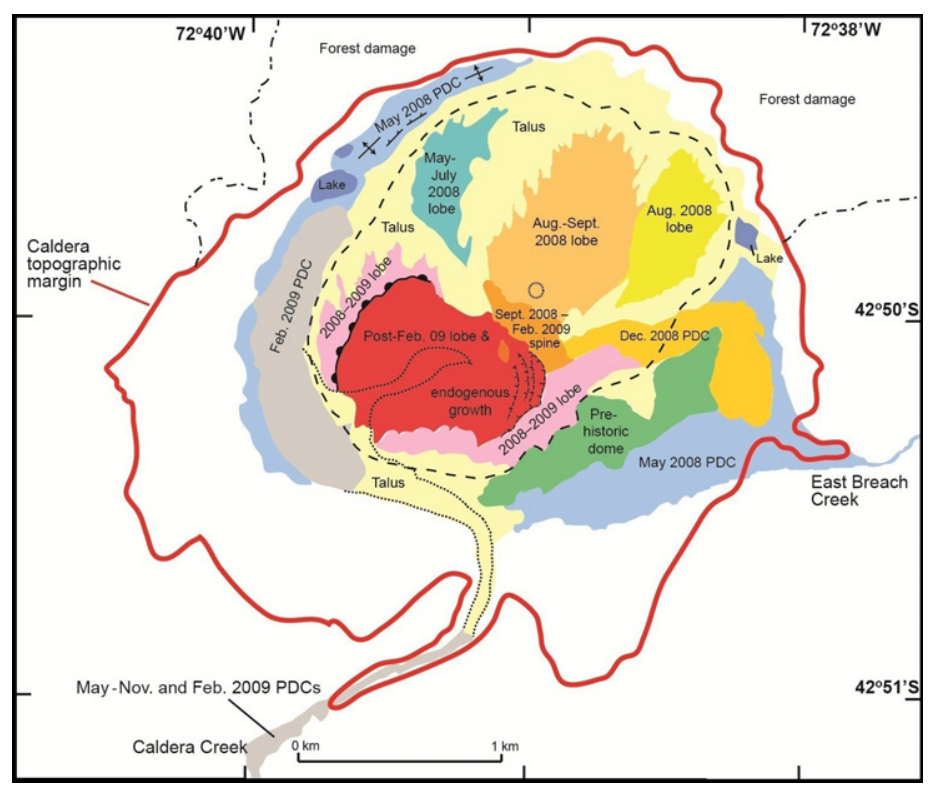

FIG. 5. Geologic map of lava dome within Chaitén caldera, as it appeared in January 2010. Labels give age ranges for individual lobes and PDC deposits emplaced in 2008 (08) and 2009 (09). Talus slopes (Talus) cover buried contact of 2008-2009 lava, which is indicated by dashed line. Dotted line indicates former position of February 2009 PDC fan, which originated by collapse of September 2008-February 2009 spine, a remnant of which remains near center of the dome complex. Line decorated with half circles marks a detachment-faulted boundary produced by post-February 2009 endogenous growth. Detachment faulting during endogenous growth shifted late 2008 to early 2009 lava (08-09 lobe) to the northwest. Decorated dashed lines within area of post-February 2009 lobe and endogenous growth are normal fault scarps produced in response to collapse and lateral spreading to the west. Dashed circle near center of figure represents approximate position of main vent for May-September 2008 dome lobes. Dash-dot lines indicate areas of forest damage resulting from early May 2008 pyroclastic surges.

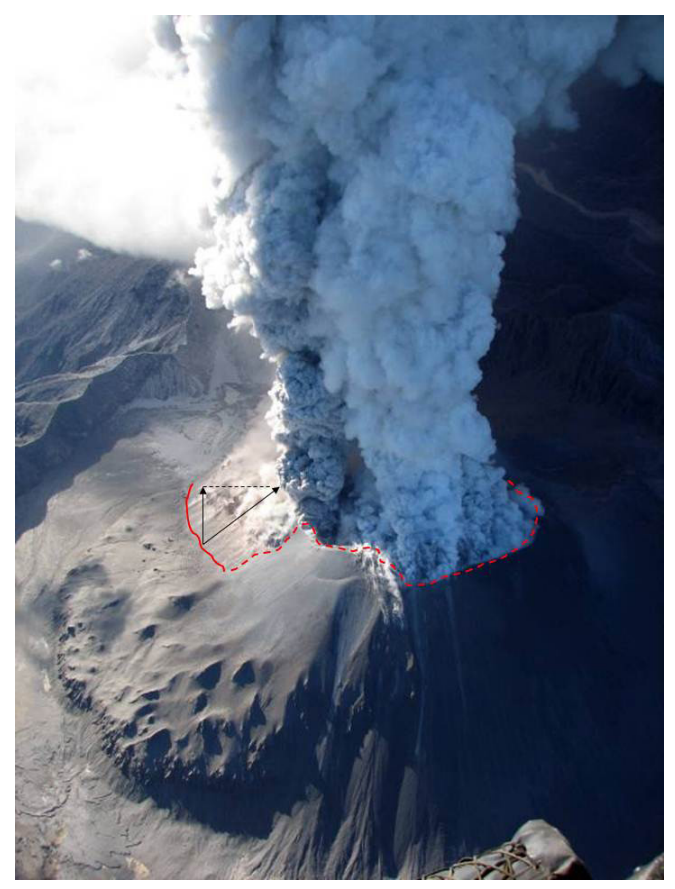

FIG. 6. Oblique aerial photograph from helicopter on 26 May 2008 (by Jeffrey Marso, United States Geological Survey) looking northeast showing initial stages of growth of May-July 2008 lava lobe. New lava is visible as the steaming mass and below talus in the area enclosed by the solid red line. Areas of new lava enclosed by the dashed red line. Pre-historic lava dome is visible as tephra mantled lobe in foreground. The vectors and dashed line indicate a vertically-oriented triangle used to estimate thickness of the new lava. Using the area and thickness estimated from this and other photos, we estimate an approximate area, thickness and volume of lava erupted between 11 and 26 May 2008 of $\sim 700,000 \mathrm{~m}^{2}, \sim 120 \mathrm{~m}$, and $\sim 80 \times 10^{6} \mathrm{~m}^{3}$, respectively, and yielding an average extrusion rate of about $66 \mathrm{~m}^{3} \mathrm{~s}^{-1}$. Using similar photographs combined with other images, we estimated additional eruption volumes during the first four months of the eruption and calculated average eruption rates from the change in volume with respect to time (Fig. 8). 

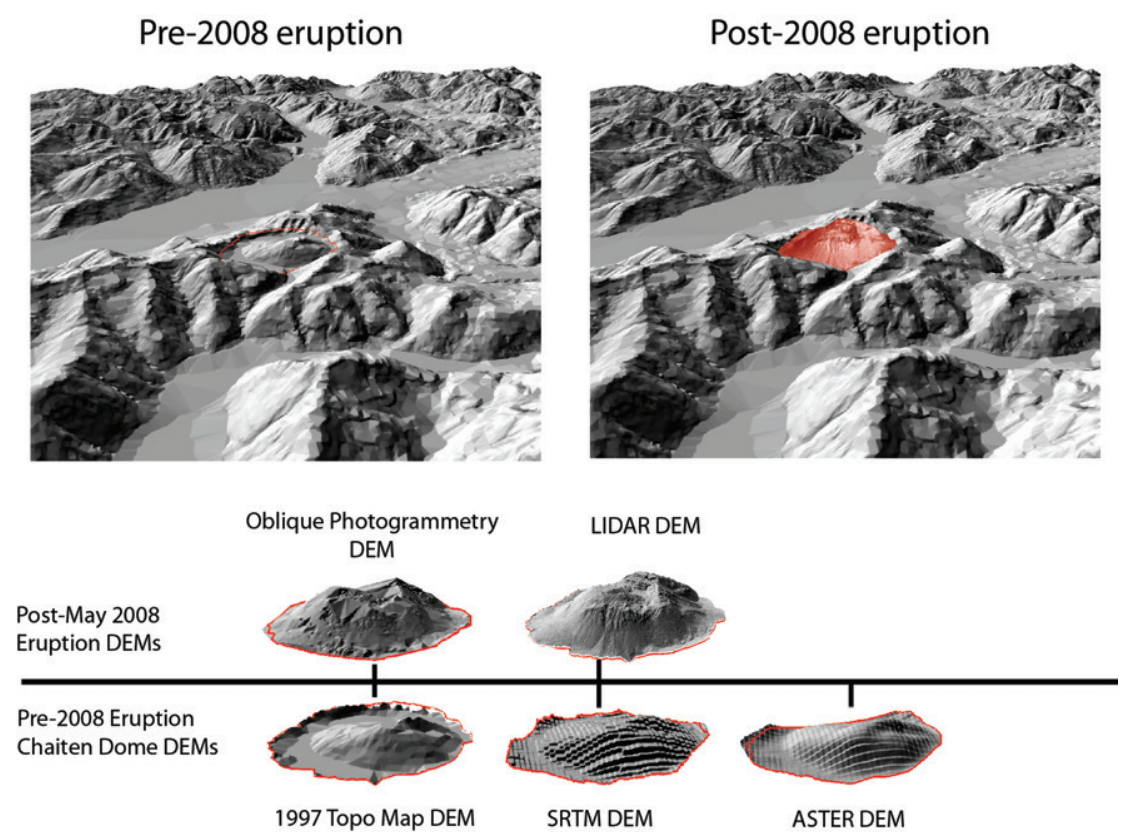

2008-2009 lava dome volume calculations

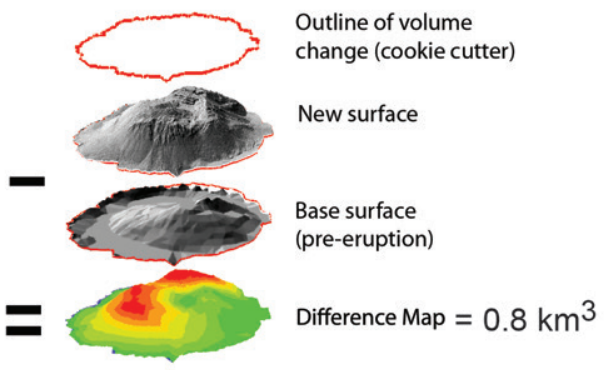

\section{Pre-Eruption lava dome volume calculations}

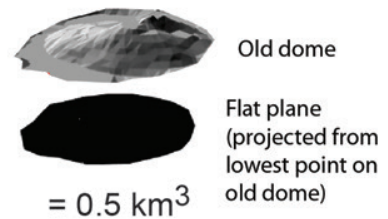

FIG. 7. Graphical portrayal of method used to calculate volume of 20082009 and pre-historic lava domes at Chaitén caldera. Two post-May 2008 DEMs and three pre-2008 DEMs were created and differenced to estimate the volume of the 20082009 lava dome. Our preferred estimate is based on differencing either the oblique photogrammetry DEM or the LIDAR DEM and the 1997 topographic map DEM. Both yield a volume of $0.8 \mathrm{~km}^{3}$, which is a minimum extruded volume as it does not include volume of December 2008 and February 2009 dome-collapse PDC deposits. Volume of pre-historic dome $\left(0.5 \mathrm{~km}^{3}\right)$ is calculated above a flat surface constructed at its base (as exposed prior to the 2008-2009 eruption). This is also a minimum volume as it does not include parts of pre-historic dome that are buried by moat deposits.

\subsection{Geochemistry and petrology}

Rock samples were collected from the 2008-2009 deposits within and near the caldera during two weeks of helicopter-assisted field work in January 2010. Sample descriptions, locations and analytical data are given in Table 1. Powdered whole-rock samples were analyzed for major-elements by X-ray fluorescence techniques at the Washington State University GeoAnalytical Lab in Pullman, Washington. Trace-elements in the same powders were analyzed by inductively coupled plasma mass spectrometry at the same laboratory. Analytical procedures and precision are discussed at http://www.sees.wsu.edu/Geolab/note.html.

Electron microprobe analyses of the minerals in the Chaitén rhyolite were done on the JEOL 8900 at the United States Geological Survey in Menlo Park, California, and results from representative analyses are listed in Table 2 . We analyzed both sparse phenocrysts in polished thin sections of rock samples as well as grains in mineral separates (prepared to provide more representative suites of minerals from the crystal-poor Chaitén rhyolite). Microprobe standards included a variety of well characterized natural minerals (Tiburon albite, sodalite, barite, Wilberforce apatite) and simple elemental oxides $\left(\mathrm{MgO}, \mathrm{TiO}_{2}, \mathrm{MnO}_{3}\right)$ that are in standard use at the Menlo Park facility. In this work we focus on data that bear on the origin and viscosity of the rhyolite magma. Data and interpretations concerning partitioning of halogen gases are given in a separate paper (Lowenstern et al., 2012). 


\section{Results}

\subsection{Eruptive sequence}

On the basis of observations and photographs by the Servicio Nacional de Geología y Minería (SERNAGEOMIN, 2008; Basualto et al., 2009), reports by residents of the area and our geologic mapping (Fig. 5) we divide the 2008-2009 eruption of Chaitén into five phases.

1. Explosive phase. This phase began late on 1 May 2008 (local time) or early on 2 May 2008 (UTC) and had a volcanic explosivity index (VEI) between 4 and 5 (Carn et al., 2009; Watt et al., 2009; Alfano et al., 2011). It produced spectacular Plinian ash columns suffused with lightning. The ash columns reached altitudes of $19-21 \mathrm{~km}$ and the resulting ash clouds produced extensive ash fall, mainly to the east and southeast of the volcano across Argentina and out to the Atlantic Ocean. SERNAGEOMIN (2008), Folch et al. (2008), Alfano et al. (2011) and Durant et al. (2012) describe high-altitude ash columns on 1-2 May, 3-5 May, and 6 May. The total volume of the bulk tephra erupted between 1 May 2008 and January 2009 is estimated by Alfano et al. (2011) to be between 0.5 and $1.3 \mathrm{~km}^{3}$, most of which was erupted during the 1-6 May 2008 Plinian eruptions. These Plinian eruptions emanated from two vents on the north side of the pre-historic lava dome. The two vents merged into a single vent on 6 May (SERNAGEOMIN, 2008). The early May 2008 eruptions included directed blasts to the north and northeast, possibly on 2 May (Major et al., 2013, this volume), as well as column-collapse pyroclastic density currents (PDCs) that accumulated to produce un-welded deposits mainly within the caldera and in the headwaters of East Breach Creek ('May 2008 PDC', Fig. 5). Rainfall-induced lahars and floods mobilized the tephra fall deposits beginning on 11-12 May (SERNAGEOMIN, 2008; Pierson et al., 2013); these and subsequent floods devastated much of Chatén town.

2. Transitional phase. Beginning on 11 May and continuing through the end of the month, a transition from explosive to effusive activity took place. Aerial photographs show that vertical ash columns and lava effusion occurred simultaneously and from the same vents during this phase (Fig. 6).

3. Exogenous lava flow phase. During June through September 2008 a large volume of lava $\left(\sim 0.5 \mathrm{~km}^{3}\right)$ was erupted in the northern and western sectors of the caldera (May-July 08, Aug. 08, and Aug.-Sept. 08 lobes, Fig. 5) and buried most of Chaitén's pre-historic lava dome. By January 2009, the May 2008 lobe had developed a spiny surface and a ramp-like shear-lobe structure, whereas the August 2008 and August-September 2008 lobes are classified as coulees (Bernstein et al., 2013, this volume).

4. Spine extrusion phase. Beginning in October 2008 and continuing until 19 February 2009 a prominent Peléean spine grew from the central vent area of the new lava dome (Fig. 3). Endogenous dome growth also took place in the adjacent central area of the now-composite lava dome ('2008-2009 lobe', Fig. 5). Small collapses of the lava dome took place in January and early February 2009. However, on 19 February 2009 a major collapse removed about $10 \%$ of the new lava dome and fed a block-and-ash flow PDC ('Feb. 2009 PDC', Fig. 3) that exited the caldera through the pre-existing Caldera Creek drainage to the south and flowed down the Chaitén River to within 3 kilometers of Chaiten town (SERNAGEOMIN, 2008; Duhart et al., 2009; Pallister et al., 2010; Major et al., 2013, this volume). The collapse eroded into the adjacent areas of the composite lava dome, producing a deep reentrant in its western face (Fig. 3 and dotted line in Fig. 5). In the days to weeks following the 19 February collapse, additional headward collapses within the reentrant led to collapse of the spine.

5. Endogenous growth phase. This phase began with lava extrusion following the 19 February 2009 spine collapse, but then shifted to mainly endogenous growth, characterized by magma intruding beneath and inflating previously erupted lobes ('PostFeb. 2009 lobe and endogenous growth', Fig. 5). The February collapse-generated reentrant was filled in by new lava, and as endogenous growth took place earlier phases of the dome were thrust outward and away from the vent area (Fig. 5). This phase of endogenous growth gradually slowed but persisted until the eruption effectively ended by late 2009 or earliest 2010 . 
TABLE 1. WHOLE-ROCK MAJOR AND TRACE ELEMENT COMPOSITIONS DETERMINED BY XRF AND ICP-MS

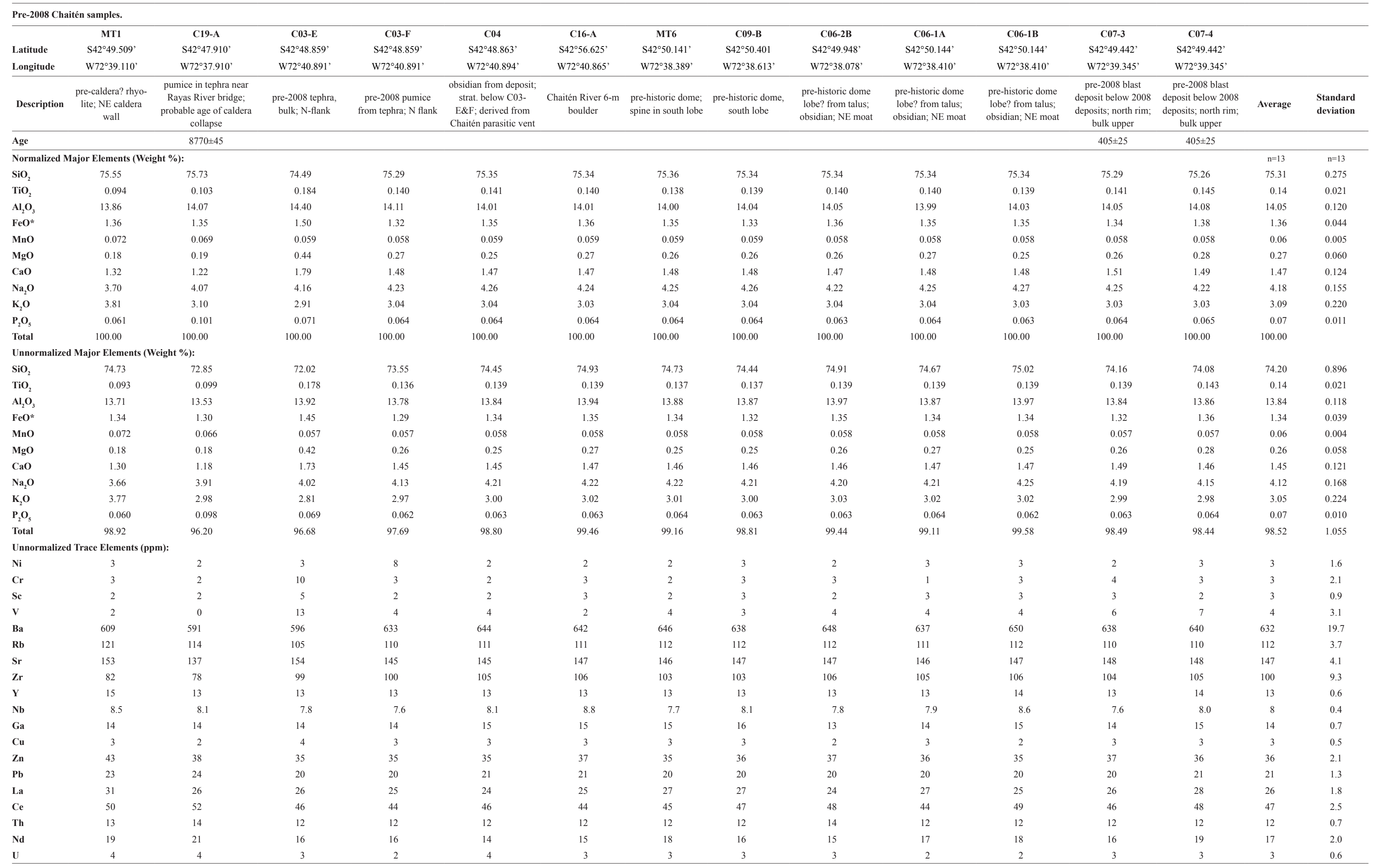


Table 1. continued.

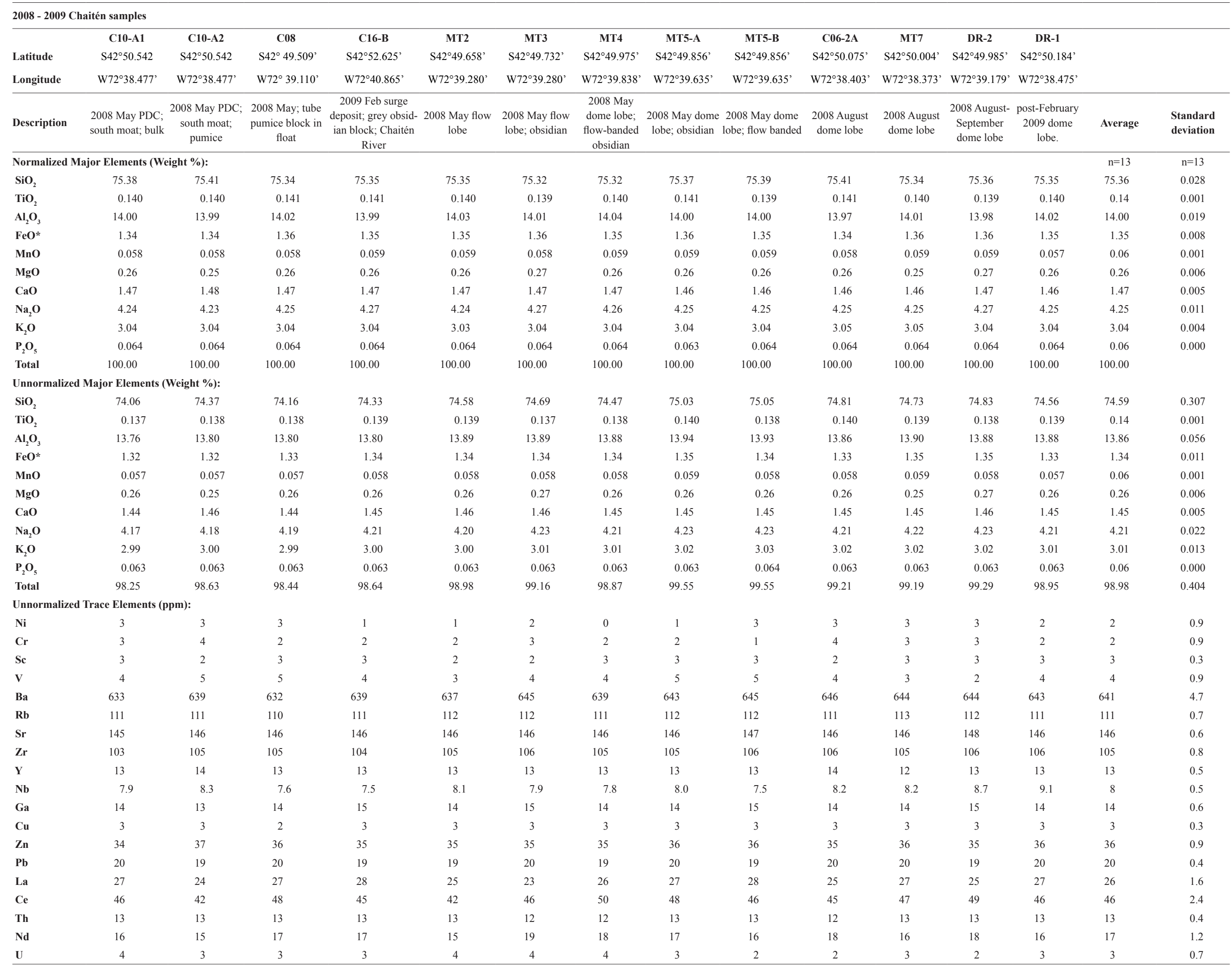

Ages expressed in ${ }^{14} \mathrm{C}$ years. ${ }^{*} \mathrm{FeO}=$ total $\mathrm{Fe}$ expressed as $\mathrm{FeO}$. 
TABLE 2. REPRESENTATIVE ELECTRON MICROPROBE ANALYSES OF CRYSTALS IN CHAITÉN RHYOLITES.

\begin{tabular}{|c|c|c|c|c|c|c|c|c|c|c|c|}
\hline Sample & CH-4 & CH-4 & CH-4 & CH-4 & CH-4 & CH-4 & CH-4 & CH-4 & CH-4 & CH-4 & CH-4 \\
\hline Spot \# & 14 & 15 & 16 & 17 & 18 & 19 & 14-1 & $14-4$ & $14-5$ & 2-Oct. & 3-Oct \\
\hline Mineral & p-core & $\mathrm{p}$ & $\mathrm{p}$ & $\mathrm{p}$ & $\mathrm{p}$ & $\mathrm{p}$ & o & o & o & o & o \\
\hline Date & 8-Nov. & 8-Nov. & 8-Nov. & 8-Nov. & 8-Nov. & 8-Nov. & 8-Jul. & 8-Jul. & 8-Jul. & 8-Jul. & 8-Jul. \\
\hline $\mathrm{SiO}_{2}$ & 45.11 & 53.74 & 55.01 & 54.65 & 55.83 & 55.85 & 52.71 & 52.16 & 52.37 & 51.38 & 51.33 \\
\hline $\mathrm{TiO}_{2}$ & - & - & - & - & - & - & 0.12 & 0.19 & 0.18 & 0.08 & 0.08 \\
\hline $\mathrm{Al}_{2} \mathrm{O}_{3}$ & 34.4 & 27.93 & 26.89 & 27.13 & 26.47 & 27.04 & 0.86 & 1.46 & 1.41 & 1.11 & 1.18 \\
\hline $\mathrm{FeO}$ & 0.41 & 0.32 & 0.29 & 0.27 & 0.20 & 0.22 & 20.36 & 20.69 & 20.71 & 26.24 & 26.46 \\
\hline MnO & - & - & - & - & - & - & 0.93 & 0.76 & 0.76 & 1.20 & 1.22 \\
\hline MgO & 0.06 & 0.07 & 0.07 & 0.07 & 0.08 & 0.07 & 23.57 & 22.95 & 22.83 & 19.52 & 19.51 \\
\hline $\mathrm{CaO}$ & 16.73 & 9.49 & 8.40 & 8.97 & 7.58 & 8.31 & 0.68 & 0.90 & 0.97 & 0.44 & 0.46 \\
\hline $\mathrm{Na}_{2} \mathrm{O}$ & 2.06 & 6.67 & 7.41 & 7.28 & 7.73 & 7.34 & - & - & - & - & - \\
\hline $\mathrm{K}_{2} \mathrm{O}$ & 0.12 & 0.27 & 0.30 & 0.30 & 0.36 & 0.35 & - & - & - & - & - \\
\hline Total & 98.89 & 98.49 & 98.36 & 98.67 & 98.23 & 99.17 & 99.23 & 99.11 & 99.23 & 99.98 & 100.23 \\
\hline
\end{tabular}

$\begin{array}{llllllllllr}\text { Ab, Fs } & 0.18 & 0.55 & 0.60 & 0.59 & 0.64 & 0.60 & 0.68 & 0.66 & 0.66 & 0.58 \\ \text { Or, En } & 0.01 & 0.01 & 0.02 & 0.02 & 0.02 & 0.02 & 0.31 & 0.32 & 0.32 & 0.41 \\ \text { An, Wo } & 0.81 & 0.43 & 0.38 & 0.40 & 0.34 & 0.38 & & & \\ & 0.01 & 0.02 & 0.02 & 0.01 & 0.01 & & \end{array}$

\begin{tabular}{|c|c|c|c|c|c|c|c|c|c|c|c|c|}
\hline Sample & CH-4 & CH-4 & CH-4 & CH-4 & CH-4 & $\mathrm{CH}-4$ & CH-4 & MT2 & MT2 & MT3 & MT4 & C10D2 \\
\hline Spot \# & 55 & 57 & 58 & 32 & 33 & 34 & 36 & 30 & 23 & 38 & 59 & 63 \\
\hline Mineral & $\mathrm{a}$ & $\mathrm{a}$ & a & a & $\mathrm{a}$ & $\mathrm{a}$ & $\mathrm{a}$ & $\mathrm{b}$ & $\mathrm{b}$ & $\mathrm{b}$ & $\mathrm{b}$ & b \\
\hline Date & 8-Jul. & 8-Jul. & 8-Jul. & 8-Jul. & 8-Jul. & 8-Jul. & 8-Jul. & 10-Aug. & 10-Aug. & 10-Aug. & 10-Aug. & 10-Aug. \\
\hline $\mathrm{SiO}_{2}$ & 43.92 & 40.30 & 44.29 & 41.77 & 42.07 & 40.56 & 39.39 & 37.77 & 39.21 & 38.50 & 36.58 & 52.95 \\
\hline $\mathrm{TiO}_{2}$ & 0.72 & 2.44 & 1.32 & 1.42 & 1.92 & 2.52 & 3.03 & 2.66 & 3.09 & 0.57 & 2.47 & 1.21 \\
\hline $\mathrm{Al}_{2} \mathrm{O}_{3}$ & 11.04 & 12.22 & 8.71 & 11.64 & 10.81 & 12.61 & 13.59 & 14.48 & 14.58 & 13.94 & 14.51 & 13.35 \\
\hline $\mathrm{FeO}$ & 13.83 & 13.02 & 11.03 & 13.96 & 12.86 & 14.40 & 11.61 & 17.66 & 18.18 & 22.85 & 18.44 & 10.79 \\
\hline MgO & 10.74 & 11.02 & 12.51 & 12.13 & 12.69 & 10.64 & 12.10 & 12.82 & 11.87 & 12.18 & 13.04 & 6.64 \\
\hline MnO & 0.17 & 0.14 & 0.13 & 0.13 & 0.09 & - & - & - & - & - & - & - \\
\hline $\mathrm{CaO}$ & 11.18 & 9.95 & 11.41 & 9.41 & 9.88 & 10.18 & 10.97 & 0.02 & 0.01 & 0.03 & 0.01 & 0.59 \\
\hline $\mathrm{BaO}$ & 0.49 & 0.54 & 0.17 & 0.45 & 0.32 & - & - & - & - & - & - & - \\
\hline $\mathrm{Na}_{2} \mathrm{O}$ & 1.80 & 2.63 & 1.79 & 2.38 & 2.25 & 2.59 & 2.67 & 1.08 & 1.19 & 1.09 & 0.83 & 1.29 \\
\hline $\mathrm{K}_{2} \mathrm{O}$ & 0.28 & 0.40 & 0.32 & 0.41 & 0.38 & 0.40 & 0.41 & 7.64 & 7.71 & 7.56 & 7.73 & 5.55 \\
\hline $\mathbf{F}$ & 1.11 & 0.48 & 0.30 & 0.82 & 0.25 & - & - & - & - & - & - & - \\
\hline CI & 0.17 & 0.13 & 0.14 & 0.13 & 0.10 & - & - & - & - & - & - & - \\
\hline Total & 93.51 & 91.97 & 91.38 & 93.13 & 92.86 & 93.9 & 93.77 & 96.08 & 97.13 & 97.44 & 95.13 & 93.12 \\
\hline
\end{tabular}

Sample numbers refer to samples described in Table 1. Samples CH-4, MT2, and C10D2 are characteristic crystal-poor rhyolite lava from lobes of the indicated dates. Spot \# refers to individual analysis identification number. Mineral: $\mathbf{p}=$ plagioclase; $\mathbf{0}=$ orthopyroxene; $\mathbf{a}=$ amphibole; $\mathbf{b}=$ biotite; $\mathbf{A b}, \mathbf{F s}=$ albite component in plagioclase, Ferrosalite in orthopyroxene; $\mathbf{O r}, \mathbf{E n}=$ orthoclase component in plagioclase, enstatite in orthopyroxene; An, $\mathbf{W o}=$ anorthite component in plagioclase, wollastonite in orthopyroxene. Dashes indicate not analyzed or below detection limit. 


\subsection{Photogrammetry and GIS}

The total volume of extruded lava erupted in 20082009 is $\sim 0.8 \mathrm{~km}^{3}$. Our estimate of the lava effusion rate for first two weeks is $66 \mathrm{~m}^{3} \mathrm{~s}^{-1}$ (Fig. 6) and for the first four months the rate averaged $45 \mathrm{~m}^{3} \mathrm{~s}^{-1}$ (value calculated from a polynomial fit to the volume-time data in Fig. 8). We estimate relative errors of $\pm 20 \%$ in our rate calculations. The cumulative volume for the first four months of the eruption is $\sim 0.5 \mathrm{~km}^{3}$, i.e. $5 / 8$ of the total volume of $0.8 \mathrm{~km}^{3}$ determined by photogrammetry. The trend in figure 8 indicates that the rate of extrusion had decreased to near-zero by the end of September 2008. Consequently, to reach the full effusive volume of $0.8 \mathrm{~km}^{3}$ eruption a second period of renewed extrusion and endogenous growth is suggested. We believe that this renewed period of growth took place during late 2008 and early 2009 , a period of spine growth, spine collapse and renewed extrusion that filled the February 2009 collapse scar. Over the entire duration of the 2008-2009 eruption (May 2008-January 2010), the averaged lava eruption rate was $\sim 16 \mathrm{~m}^{3} \mathrm{~s}^{-1}$. We note that this overall rate is a minimum as it does not include the volumes of PDC deposits from the December 2008 and February 2009 dome collapses (Fig. 5).

An independent photogrammetric analysis of oblique photographs was conducted by Valenzuela (2011), who determined an effusion rate of $\sim 27 \mathrm{~m}^{3} \mathrm{~s}^{-1}$ for the first five months (12 May-30 October 2008) of the eruption. Our estimate for the same period based on the polynomial fit in figure 8 is $30 \mathrm{~m}^{3} \mathrm{~s}^{-1}$, within error of Valenzuela's estimate.

We calculate the minimum volume of Chaitén's pre-historic intracaldera lava dome by subtracting a horizontal plane constructed at the lowest point of the caldera moat from the pre-eruption DEM, yielding $0.5 \mathrm{~km}^{3}$ (Fig. 7). This is a minimum volume for the pre-historic dome, as it does not include parts of the dome that were buried below fragmental moat deposits. Together, the two domes constitute about $20-40 \%$ of the $3.5-7 \mathrm{~km}^{3}$ collapse volume of the prehistoric caldera, which we estimate from the DEM using average and maximum heights of the rim.

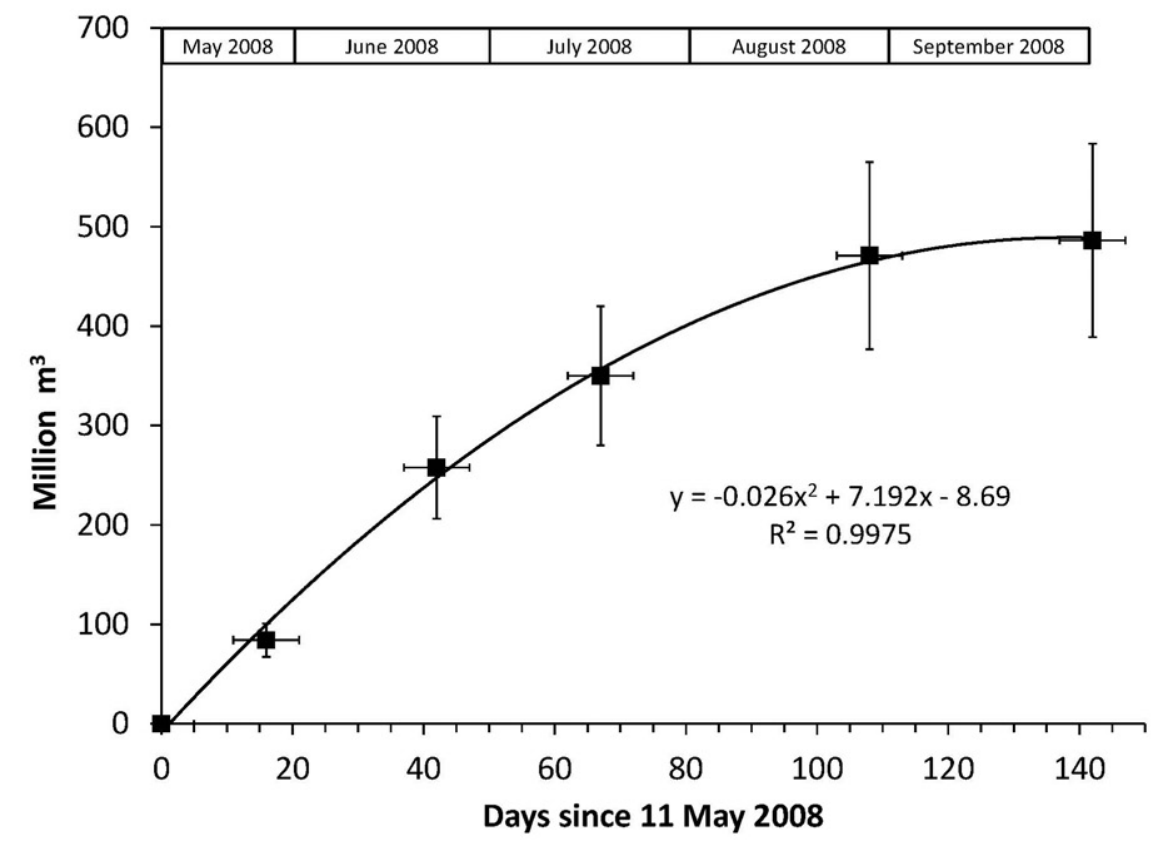

FIG. 8. Cumulative volume of newly erupted Chaitén lava dome as calculated during the period between 11 May and 30 September 2008. Estimated errors of $\pm 20 \%$ are assigned to volumes. Initial value of zero volume is set to 11 May 2008 , as first indication of dome extrusion was on 12 May 2008. Horizontal error bars indicate ranges of dates for observations used in estimations of volumes. A polynomial equation is fit to the data and shows a slowing of extrusion rate with time. Applying this equation $\left(y=-0.026 \mathrm{x}^{2}+7.192 \mathrm{x}-8.69\right)$ and converting from units of $\mathrm{m}^{3} \mathrm{~d}^{-1}$ to $\mathrm{m}^{3} \mathrm{~s}^{-1}$ yields an average effusion rate of $45 \mathrm{~m}^{3} \mathrm{~s}^{-1}$ for the first four months of lava dome eruption. 


\subsection{Petrography and geochemistry}

Here we provide a brief summary of the petrography and geochemistry of rhyolite erupted during 2008-2009 in the Chaitén area. We focus on petrologic and geochemical factors that affect eruption rates. We also compare the 2008-2009 compositions to those erupted during prehistoric time in the Chaitén area. Table 1 lists locations, descriptions and major and trace-element chemistry of the samples. Additional details of the petrology of these rhyolite samples are given in Castro and Dingwell (2009) and Lowenstern et al. (2012).

All of the 2008-2009 Chaitén rhyolites are phenocryst-poor ( $\sim 0.1$ vol.\% phenocrysts) with mainly plagioclase and subordinate amounts of orthopyroxene and oxide minerals. Biotite or amphibole phenocrysts are also present in some thin sections. Mineral separates show that the 2008-2009 rhyolite also contains accessory zircon, apatite and pyrrhotite. We found hornblende but no biotite as phenocrysts in mineral separates from lump pumice that was collected on 20 May 2008 from a beach at Auchemo, $\sim 25 \mathrm{~km}$ southwest of Chaitén. This pumice had apparently been carried west during flooding caused by heavy rainfall after the initial week of eruptions, but prior to May 20 and it is interpreted as a product of the initial early-May 2008 Plinian eruption (A. Lockhart, USGS; personal communications, 5 September 2008 and 15 October 2012). The plagioclase crystals are subhedral to euhedral, though even well-formed crystals have slightly rounded edges. In general, the mafic minerals retain more euhedral crystal shapes. Though the amphiboles in the pumice sample from Auchemo are not euhedral, they lack the marginal reaction rinds that are generally attributed to dehydration accompanying decompression (Rutherford et al., 1998; McCanta et al., 2007) or possibly to heating (De Angelis et al., 2012).

Rhyolite pumice and obsidian lapilli occur together in the May 2008 Plinian deposits, but the abundance of water and the degree of microlite crystallization are different in the two lapilli types (Lowenstern et al., 2012). Pumiceous glass is nearly anhydrous with $<0.2 \%$ wt. $\% \mathrm{H}_{2} \mathrm{O}$, whereas glass from two studied obsidian lapilli contained $\sim 0.8$ wt. $\% \mathrm{H}_{2} \mathrm{O}$ (analyses by Fourier transform infrared spectrometry). Other samples of the 2008-2009 rhyolite lava are visibly more crystalline; backscatter electron image maps reveal that they contain abundant microlites of plagioclase, orthopyroxene and oxide. There are no hydrous microlites (biotite or amphibole) in the Chaitén samples. Silicate melt inclusions are common in all studied phases of the rare phenocrysts. The melt inclusions are predominantly glassy and contain small $(5-15 \mu \mathrm{m})$ shrinkage bubbles that make up an estimated 1 to 5 volume percent of the inclusions.

Castro and Dingwell (2009) and Lowenstern et al. (2008) reported that plagioclase grains in the 2008 pumice are mainly $\mathrm{An}_{40-45}$; however, we also found rare cores as calcic as $\mathrm{An}_{81}$ (Table 2). Orthopyroxenes are typically $\mathrm{En}_{50-55}$ and amphiboles are more aluminous and more calcic (Table 2) than expected for crystals forming from high-silica rhyolite magma (c.f., Table 4 of Coombs and Gardner, 2004). In addition, experiments failed to produce amphiboles at reasonable temperatures $\left(775-850^{\circ} \mathrm{C}\right)$ and water concentrations (4-6 wt.\%) from the whole-rock pumice erupted at Chaitén (Castro and Dingwell, 2009; written communication T. Sisson and J. Lowenstern, 2008).

\subsection{Whole-rock chemistry and comparison of 2008-2009 and prehistoric lava}

The whole-rock compositions of the 2008-2009 eruptive products from Chaitén are strikingly similar to and overlap completely with the pre-historic dome (Table 1 and Muñoz et al., 2009b) and they contain the same suite of phenocryst minerals (mainly plagioclase, orthopyroxene, and oxides). The entire suite of Chaitén rhyolites (pre-historic and 2008-2009) are remarkably uniform in composition with $75.36 \pm 0.028 \% \mathrm{SiO}_{2}, 14.0 \pm 0.019 \% \mathrm{Al}_{2} \mathrm{O}_{3}$, $0.26 \pm 0.006 \% \mathrm{MgO}, 1.47 \pm 0.005 \% \mathrm{CaO}, 4.25 \pm 0.011 \%$ $\mathrm{Na}_{2} \mathrm{O}$ and $3.04 \% \pm 0.004 \% \mathrm{~K}_{2} \mathrm{O}$ (Table 1). The relatively low alkali content for a rhyolite creates a slightly peraluminous ( $0.74 \mathrm{wt} . \%$ corundum $)$ and orthopyroxene-bearing normative rock composition. Trace-elements are also remarkably similar among the 2008-2009 and pre-historic rhyolite samples. Strontium concentrations are relatively high $(\sim 145 \mathrm{ppm})$ and exceed $\mathrm{Rb}(\sim 110 \mathrm{ppm})$ and the rare-earth element (REE) patterns show broadly concavedownward patterns with minor Eu-anomalies (Fig. 9). Due to the low abundance of phenocrysts, glass compositions in all the Chaitén rhyolites are essentially identical in composition to those of the whole-rock samples. 


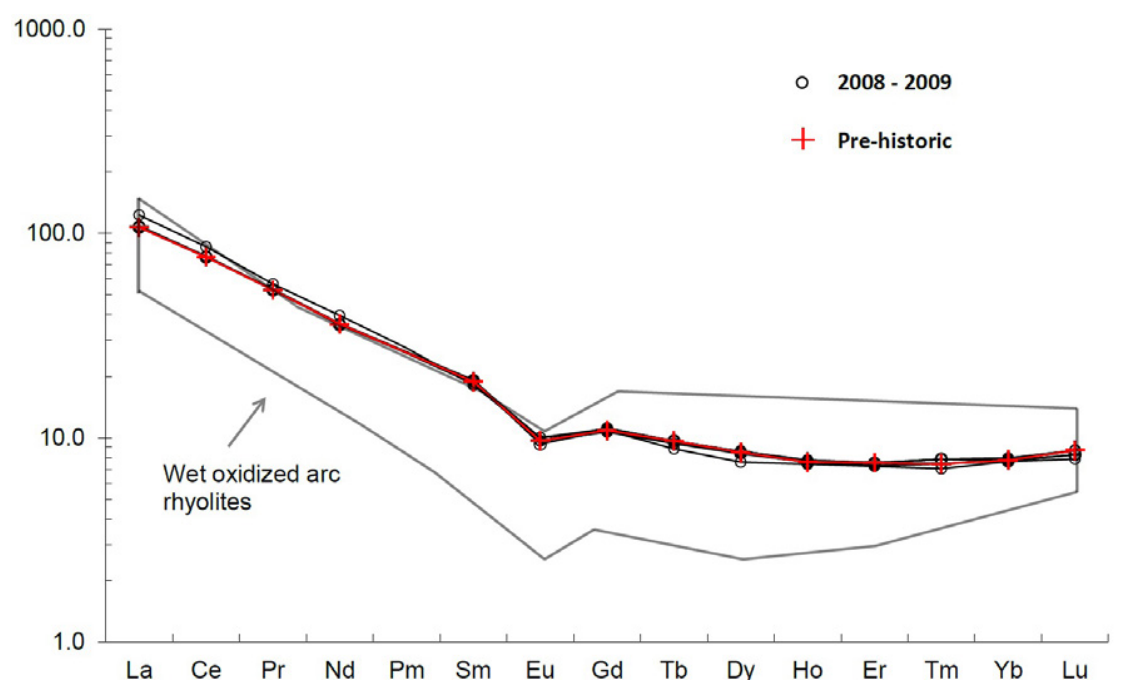

FIG. 9. Chondrite-normalized rare-earth element diagram, modified from Lowenstern et al. (2012), comparing abundance patterns for 9 samples from the 2008-2009 eruption to a sample of the pre-historic Chaitén dome and to the field of 'wet oxidized rhyolites' of Bachman and Bergantz (2008).

\section{Discussion and conclusions}

\subsection{Origin of the rhyolite magma}

The 2008-2009 rhyolite's normative composition plots close to that of relatively low pressure (100$200 \mathrm{MPa}$ ) minimum melt in the haplogranite system (Fig. 10), consistent with the pressure estimates based on phase equilibria (Castro and Dingwell, 2009) and model depths from geodesy (5-9 km; Wicks et al., 2011). These data, as well as radiogenic $\mathrm{Sr}, \mathrm{Nd}$ and $\mathrm{Pb}$ isotopic ratios (Muñoz et al., 2012), favor a shallow crustal origin for the rhyolite magma. Calcic plagioclase cores, relatively magnesian orthopyroxene and the presence of relatively calcic and aluminumrich amphibole suggest that the rhyolite was derived by melt extraction from a more mafic (diorite to granodiorite) magmatic mush at these shallow crustal depths, an origin also favored for voluminous rhyolite erupted at Alaska's Katmai-Novarupta caldera system in 1912 (Hildreth and Fierstein, 2012). The REE patterns for the Chaitén rhyolites in figure 9 are similar to other 'wet oxidized rhyolites' (Bachman and Bergantz, 2008) interpreted as melt extracts from granodioritic crystal mushes in which plagioclase crystallization is delayed and amphibole and titanite are retained in the mush (conditions that reduce the extent of the Eu-anomaly and result in high $\mathrm{Sr}$ relative to $\mathrm{Rb}$ in the rhyolite extract).

\subsection{Rapid ascent and rapid rates of lava effusion}

Castro and Dingwell (2009) reported mineral assemblages in Chaitén pumice similar to those we report here. Based on Fe-Ti oxide thermometry and equilibria experiments for the last-crystallized phases, they determined a magmatic storage temperature of $\sim 800^{\circ} \mathrm{C}$ at a pressure of $120-200 \mathrm{MPa}$ (a depth range of about 5-10 km). Furthermore, using experimental calibration of plagioclase rim overgrowths, they estimate decompression rates of $>40 \mathrm{MPah}^{-1}\left(>0.5 \mathrm{~ms}^{-1}\right)$ from a depth of $>5 \mathrm{~km}$ during a period of $\sim 4$ hours preceding the initial eruption. Several percent of $\mathrm{H}_{2} \mathrm{O}$ was lost during this ascent, as indicated by the low residual $\mathrm{H}_{2} \mathrm{O}$ contents of the 2008-2009 pumice. Castro and Dingwell (2009) note that the viscosity of the Chaitén magma was low $\left(\sim 10^{6}\right.$ to $\left.10^{8} \mathrm{~Pa} \mathrm{~s}\right)$ - an order of magnitude lower than critical values required for glass transition and autobrecciation. These data indicate that the Chaitén rhyolite was very fluid and that it ascended rapidly to near-vent level, losing several percent $\mathrm{H}_{2} \mathrm{O}$ enroute and undergoing the explosive fragmentation that powered the initial Plinian columns.

Our extrusion rate estimates of $66 \mathrm{~m}^{3} \mathrm{~s}^{-1}$ for the first two weeks and $45 \mathrm{~m}^{3} \mathrm{~s}^{-1}$ for the first four months of the eruption at Chaitén are among the highest for historical lava-dome-forming eruptions (Fig. 11). High rates of extrusion are generally attributed to 


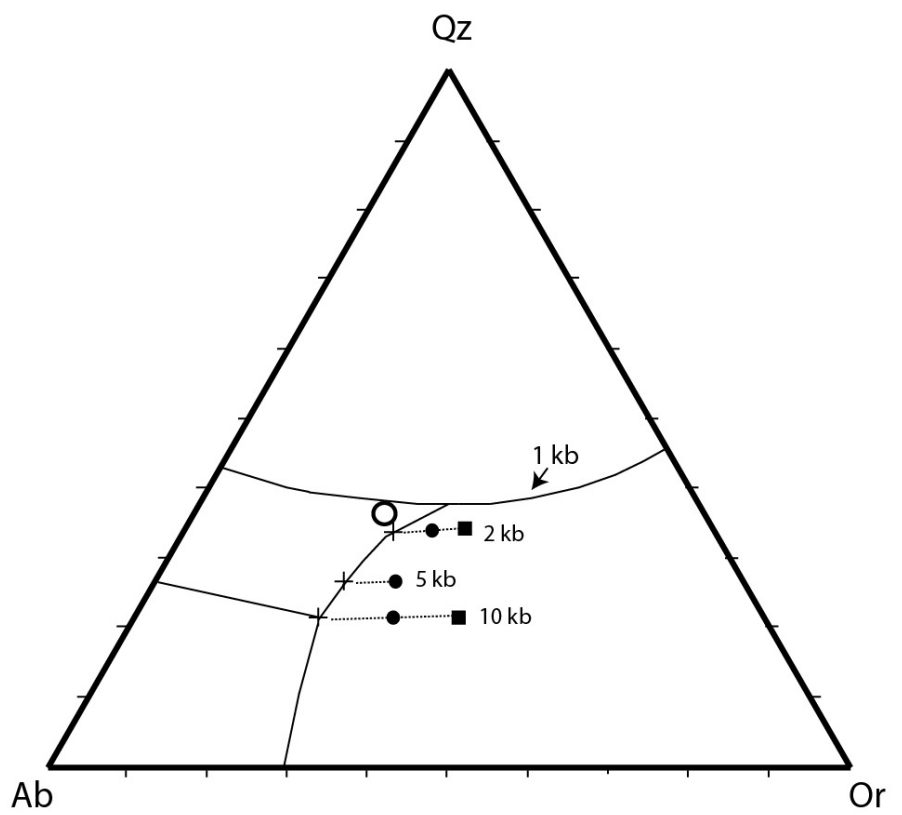

FIG. 10. Minimum and eutectic compositions for haplogranite system Quartz (Qz) - Albite (Ab) - Orthoclase (Or) comparing normative composition of the 2008-2009 Chaitén rhyolite (open circle) to experimental results. Crosses: results for $\mathrm{a}_{\mathrm{H}_{2} \mathrm{O}}=1.0(1$ and 2 kbar from Tuttle and Bowen 1958; 5 and 10 kbar from Luth et al. 1964). Dots: $\mathrm{a}_{\mathrm{H}_{2} \mathrm{O}}=0.5$; squares: $\mathrm{a}_{\mathrm{H}_{2} \mathrm{O}}=0.3$. The 2 kbar data are from Holtz et al. $(1989 ; 1992)$.

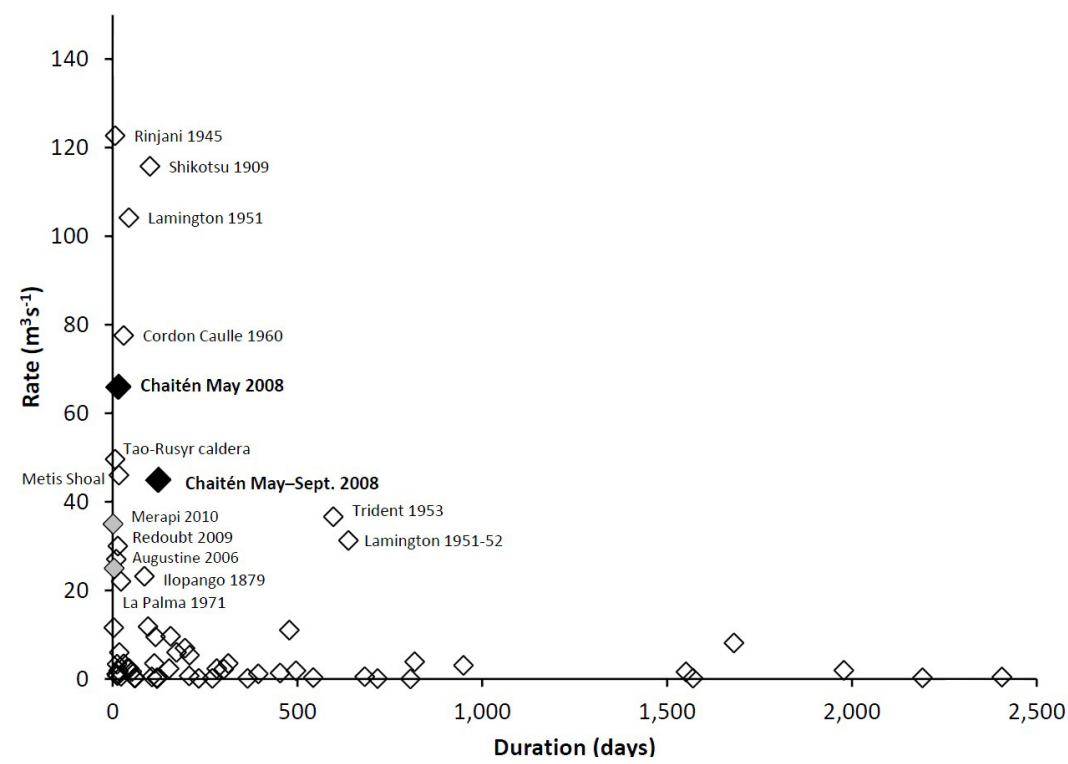

FIG. 11. Average extrusion rates for lava domes. Updated from Newhall and Melson (1983) with newer data from Redoubt (Miller, 1994; Diefenbach et al., in press), Merapi (Hammer, et al., 2000; Pallister et al., in press; Radomopurbo et al., in press) and additional unpublished data from other volcanoes, compiled by C.G. Newhall and J.S. Pallister. For Chaiten, the average rate for the first two weeks of dome extrusion $\left(66 \mathrm{~m}^{3} \mathrm{~s}^{-1}\right)$ and the first four months $\left(45 \mathrm{~m}^{3} \mathrm{~s}^{-1}\right)$ are shown as black diamonds. Gray diamonds show rates of dome extrusion at Merapi volcano on 1-4 November $2010\left(25 \mathrm{~m}^{3} \mathrm{~s}^{-1}\right)$ and 6 November $2010\left(35 \mathrm{~m}^{3} \mathrm{~s}^{-1}\right)$. Omitted is the extremely high rate for the 62-day Cordón Caulle, Chile 1921 eruption ( $\sim 60 \mathrm{~m}^{3} \mathrm{~s}^{-1}$; Newhall and Melson, 1983). Also omitted are low-rate and extremely long-duration eruptions (e.g., Santiaguito, Guatemala). 
combinations of low magma viscosity, high conduit pressure and large vent size, and in turn, magma viscosity and extrusion pressure are related to gas, crystal and bubble content and to magma ascent velocity at shallow levels (Melnik and Sparks,2009). As reviewed above, we know from the experimental work of Castro and Dingwell (2009) and the low phenocryst content of the rock samples that the Chaitén rhyolite was a hot, low viscosity magma. The explosive nature of the 1-6 May 2008 eruptions, presence of tubular pumice (indicative of gas streaming, probably at conduit margins) and high eruption columns (Carn et al., 2009) indicate rapid gas loss during the initial explosive phase of the eruption. In contrast to the comparably rapid but fissure-fed extrusion of rhyolite at Cordón Caulle in 1960 (Lara et al., 2004), we know from visual observations at Chaitén that the initial vents for the 2008 eruption were circular and relatively small and that they penetrated and did not significantly destroy or excavate the pre-historic dome (SERNAGEOMIN, 2008; Major et al., 2013, this volume). Rapid effusion at Chaitén cannot be explained as a result of a large (i.e., fissure) vent. The presence of small circular vents and lack of disruption of the pre-historic dome suggest high-strength wall rocks surrounding the shallow conduit, resulting in high-strength vent nozzles.

We attribute the initial explosive Plinian phase of the eruption to high pressure and explosive fragmentation of the hot, low-viscosity Chaitén magma as it accelerated through the small high-strength vents. The high pressure and small vent sizes contributed to the high altitude of the initial eruption columns. The presence of pumice with tube-shaped vesicles and hydrous obsidian lithic fragments in the initial PDC and tephra deposits (Lowenstern et al., 2008; 2012) indicates retention of relatively gas-rich magma to shallow crustal levels. We suggest that the initial Plinian phase of the eruption tapped the most gasrich vanguard magma in the conduit and underlying magma reservoir. The subsequent transitional, lava flow, spine and endogenous phases of the eruption then tapped progressively gas-depleted magma. Decreasing extrusion pressure (and gas content) is indicated by: 1. the transitional phase of the eruption between 11 May 2008 and the end of May 2008, during which simultaneous and rapid extrusion of lava and low-level explosive ash columns took place (e.g., Fig. 6); and 2. the progressively decreasing lava extrusion rates over the course of the eruption (Fig. 8). Overall, we propose that the remarkably rapid rates of rhyolite lava effusion at Chaitén were a consequence of the high temperature and low viscosity of the crystalpoor magma, coupled with high ascent rates. The high ascent rates allowed retention of volatiles and consequent high magma pressure in the reservoirconduit system, which in turn sustained the high rates of effusion.

\section{Acknowledgments}

We thank Ambassador P. Simons, Environment, Science, and Technology Officer M. Brett Rogers-Springs, and Economic and Political Affairs Officer G. Choi of the United States Embassy, Santiago, for their keen interest and support. We also thank former National Director A. Vio and Geological Branch Director W. Vivallo of the Servicio Nacional de Geología y Minería (SERNAGEOMIN), and F. Gil, Chief of SERNAGEOMIN's Observatorio Volcanológico de los Andes del Sur (OVDAS), for their strong support and ongoing collaboration. We acknowledge exceptional helicopter support from pilot R. Prieto of FAASA Aviación as well as L. Hayden and H. Bleick of the United States Geological Survey in Menlo Park, California who assisted with microprobe analyses. Funding to support our work was provided by the United States Geological Survey Volcano Hazards Program, SERNAGEOMIN's Red Nacional de Vigilancia Volcánica (RNVV) and Puerto Varas Technical Office.

\section{References}

Alfano, F.; Bonadonna, C.; Volentik, A.C.M.; Connor, C.B.; Watt, S.F.L.; Pyle, D.M.; Connor, L.J. 2011. Tephra stratigraphy and eruptive volume of the May, 2008. Chaitén eruption, Chile. Bulletin of Volcanology 73 : 613-630. doi: 10.1007/s00445-010-0428-x.

Bachman, O.; Berganz, G.W. 2008. Rhyolites and their source mushes across tectonic settings. Journal of Petrology 49: 2277-2285.

Basualto, D.; Moreno, H.; Lara, L.; Peña, P.; Muñoz, J.; Delgado, C.; Gallegos, C. 2009. Actividad sísmica relacionada con la evolución de la erupción del volcán Chaitén durante el 2008, Andes del Sur. In Congreso Geológico Chileno, No. 12, CD Rom: S7-005. Santiago.

Bernstein, M.; Pavez, A.; Varley, N.; Whelley, P.; Calder,E. 2013. Rhyolite lava dome growth styles at Chaitén Volcano, Chile (2008-2009): Interpretation of thermal imagery. Andean Geology 40 (2): 295-309.

Carey, S.; Sigurdsson, H. 1989. The intensity of plinian eruptions. Bulletin of Volcanology 51: 28-40. 
Carn, S.A.; Pallister, J.S.; Lara, L.; Ewert, J.W.; Watt, S.; Prata, A.J.; Thomas, R.J.; Villarosa, G. 2009. The unexpected awakening of Chaitén Volcano, Chile. Eos, Transactions American Geophysical Union 90 (24): 205-206. doi: 10.1029/2009EO240001.

Castro, J.M.; Dingwell, D.B. 2009. Rapid ascent of rhyolitic magma at Chaitén Volcano, Chile. Nature 461: 780-783.

Coombs, M.L.; Gardner, J.E. 2004. Reaction rim growth on olivine in silicic melts: Implications for magma mixing. American Mineralogist 89: 748-759.

De Angelis, S.H.; Larsen, J.F.; Coombs, M.L.; Dunn,A. 2012. A quantitative approach to understanding amphibole reaction rims: Texture, mineralogy, and processes of formation. In Fall Meeting American Geophysical Union, San Francisco, California, 3-7 December, Abstract V11C-2773.

Diefenbach, A.K.; Bull, K.F.; Wessels, R.L.; McGimsey, R.G. In press. Photogrammetric monitoring of lava dome growth during the 2009 eruption of Redoubt Volcano. Journal of Volcanology and Geothermal Research. doi: 10.1016/j.jvolgeores.2011.12.009.

Diefenbach, A.K.; Crider, J.G.; Schilling, S.P.; Dzurisin,D. 2012. Rapid, low-cost photogrammetry to monitor volcanic eruptions: an example from Mount St. Helens, Washington, USA. Bulletin of Volcanology 74 (2): 579 587. doi: 10.1007/s00445-011-0548-y.

Duhart, P.; Moreno, H.; Basualto, D.; Mella, M.; Muñoz,J. 2009. Erupción en curso del volcán Chaitén: productos, impactos y colapso parcial de domos del 19 de febrero de 2009. In Congreso Geológico Chileno, No. 12, CD Rom: S7-012. Santiago.

Durant, A.J.; Villarosa, G.; Rose, W.I.; Delmelle, P.; Prata, A.J.; Viramonte, J.G. 2012. Long-range volcanic ash transport and fallout during the 2008 eruption of Chaitén Volcano, Chile. Physics and Chemistry of the Earth 4546: 50-64. doi: 10.1016/j.pce.2011.09.004.

Folch A.; Jorba O.; Viramonte J. 2008. Volcanic ash forecast: Application to the May 2008 Chaitén eruption. Natural Hazards and Earth Systems Science 8: 927-940.

Hammer, J.E.; Cashman, K.V.; Voight, B. 2000. Magmatic processes revealed by textural and compositional trends in Merapi dome lavas. Journal of Volcanology and Geothermal Research 100: 165-192.

Hildreth, W.; Fierstein, J. 2012. The Novarupta-Katmai eruption of 1912-largest eruption of the twentieth century: centennial perspectives. United States Geological Survey Professional Paper 1791: 259 p.

Holtz, F.; Barbey, P.; Johannes, W.; Pichavant, M. 1989. Composition and temperature at the minimum point in the Qz-Ab-Or system for $\mathrm{H}_{2} \mathrm{O}$-undersaturated conditions: Experimental investigation. Terra Cognita 1: 271-272.
Holtz, F.; Pichavant, M.; Barbey, P.; Johannes, W. 1992. Effects of $\mathrm{H}_{2} \mathrm{O}$ on liquidus phase relations in the haplogranite system at 2 and 5 kbar. American Mineralogist 77: 1223-1241.

Lara, L.E.; Naranjo, J.A.; Moreno, H. 2004. Rhyodacitic fissure eruption in Southern Andes (Cordón Caulle; 40.5'S) after the 1960 (Mw:9.5) Chilean earthquake: a structural interpretation. Journal of Volcanology and Geothermal Research 138: 127-138.

Lara, L.E. 2009. The 2008 eruption of the Chaitén Volcano, Chile - a preliminary report. Andean Geology 36 (1): 125-129.

Lara, L.E.; Moreno, R.; Amigo, Á.; Hoblitt, R.P.; Pierson, T.C. 2013. Late Holocene history of Chaitén Volcano: New evidence for a $17^{\text {th }}$ century eruption. Andean Geology 40 (2): 249-261.

Lowenstern, J.B.; Sisson, T.W.; Pallister, J.; Lara, L.; Muñoz, J.; 2008. Explosive eruption of aphyric rhyolitic liquid during May 2008 from Chaitén Volcano, Chile. Eos, Transactions of the American Geophysical Union 89 (53) Fall Meeting Supplement, Abstract V43D-2180.

Lowenstern, J.B.; Bleick, H.; Vázquez, J.A.; Castro, J.; Larson, P. 2012. Degassing of Cl, F, Li and Be during extrusion and crystallization of the rhyolite dome at Volcán Chaitén, Chile during 2008 and 2009. Bulletin of Volcanology 74: 2303-2319. doi: 10.1007/s00445012-0663-4.

Luth, W.C.; Jahns, R.H.; Tuttle, O.F. 1964. The granite system at pressures of 4 to 10 kilobars. Journal of Geophysical Research 69: 759-773.

Major, J.J.; Lara, L.E. 2013. Overview of Chaitén Volcano, Chile, and its 2008-2009 eruption. Andean Geology 40 (2): 196-215.

Major, J.J.; Pierson, T.P.; Hoblitt, R.P.; Moreno, H. 2013. Pyroclastic density currents associated with the 2008-2009 eruption of Chaitén Volcano (Chile): Forest disturbances, deposits, and dynamics. Andean Geology 40 (2): 324-358.

Mason, B.G.; Pyle, D.M.; Oppenheimer, C. 2004. The size and frequency of the largest explosive eruptions on Earth. Bulletin of Volcanology 66: 735-748. doi: 10.1007/s00445-004-0355-9.

McCanta, M.C; Rutherford, M.J.; Hammer, J.E. 2007. Preeruptive and syn-eruptive conditions in the Black Butte, California dacite: Insight into crystallization kinetics in a silicic magma system. Journal of Volcanology and Geothermal Research 160: 263-284.

Melnik, O.; Sparks, R.S.J. 2009. Nonlinear dynamics of lava dome extrusion. Nature 402: 37-41. 
Miller, T.P. 1994. Dome growth and destruction during the 1989-1990 eruption of Redoubt Volcano. Journal of Volcanology and Geothermal Research 62: 197-212.

Muñoz, J.; Basualto, D.; Moreno, H.; Peña, P.; Mella, M. 2008. Geochemistry and magmagenesis of the early May 2008 rhyolitic magma erupted by Chaitén Volcano, Southern Andes Volcanic Zone. Eos, Transactions of the American Geophysical Union 89 (53) Fall Meeting Supplement, Abstract V43D-2181.

Muñoz, J.; Mella, M.; Moreno, H. 2009a. Petrogénesis del magma riolítico de la fase inicial explosiva de mayo 2008 del volcán Chaitén, Andes del Sur. In Congreso Geológico Chileno. No. 12, CD Rom: S7-20. Santiago.

Muñoz, J.; Basualto, D.; Delgado, C.; Gallegos, C.; Moreno H. 2009b. Asistencia geológica durante la fase explosiva inicial de mayo 2008 de la erupción del volcán Chaitén, Andes del Sur. In Congreso Geológico Chileno, No. 12, CD Rom: S7-10. Santiago.

Muñoz, J.; Duhart, P.; Lowenstern, J.; Lang, F.; Stern, C. 2012. Sr, $\mathrm{Nd}$ and $\mathrm{Pb}$ isotopic composition of Chaitén Volcano rhyolites, Andean Southern Volcanic Zone, Chile. In Congreso Geologico Chileno. No. 13, Actas: 516-518. Antofagasta.

Naranjo, J.A.; Stern, C. 2004. Holocene tephrochronology of the southernmost part $\left(42^{\circ} 30^{\prime}-45^{\circ} \mathrm{S}\right)$ of the Andean Southern Volcanic Zone. Revista Geológica de Chile. 31 (2): 225-240.

Newhall, C.G.; Melson, W.G. 1983. Explosive activity associated with the growth of volcanic domes. Journal of Volcanology and Geothermal Research 17: 111-131.

Newhall, C.G.; Self, S. 1982. The Volcanic Explosivity Index (VEI): An estimate of explosive magnitude for historical volcanism. Journal of Geophysical Research 87 (C2): 1231-1238.

Pallister, J.S.; Major, J.J.; Pierson, T.C.; Hoblitt, R.P.; Lowenstern, J.B.; Eichelberger, J.C.; Lara, L.; Moreno, H.; Muñoz, J.; Castro, J.M.; Iroumé, A.; Andreoli, A.; Jones, J.; Swanson, F.; Crisafulli, C. 2010. Interdisciplinary studies of eruption at Chaitén Volcano, Chile. Eos, Transactions American Geophysical Union 91: 381-382. doi: 10.1029/2010EO420001.

Pallister, J.S.; Schneider, D.J.; Griswold, J.P.; Keeler, R.H.; Burton, W.C.; Noyles, C.; Newhall, C.G.; Ratdomopurbo, A. In press. Merapi 2010 eruption: Chronology and extrusion rates monitored with satellite radar and used in eruption forecasting. Journal of Volcanology and Geothermal Research. doi: 10.1016/ j.jvolgeores.2012.07.012.

Pierson, T.C.; Major, J.J.; Amigo, Á.; Moreno, H. 2013. Acute sedimentation response to rainfall following the explosive phase of the 2008-2009 eruption of Chaitén Volcano, Chile. Bulletin of Volcanology 75, 723: 17 p. doi: 10.1007/s00445-013-0723-4.

Pyle, D.M. 2000. Sizes of volcanic eruptions. In the Encyclopaedia of Volcanoes, (Sigurdsson, H.; Houghton,B.; McNutt, S.R.; Rymer, H.; Stix, J., editors). Academic Press, London: 263-269.

Radomopurbo, A.; Beauducel, F.; Subandriyo, J.; Nandaka, A.; Newhall, C.G.; Suharna; Sayudi, D.S.; Suparwaka, S. In press. Overview of the 2006 eruption of Mt. Merapi. Journal of Volcanology and Geothermal Research. doi: 10.1016/j.jvolgeores.2013.03.019

Rutherford, M.J.; Devine, J.D.; Barclay, J. 1998. Changing magma conditions and ascent rates during the Soufrière Hills eruption on Montserrat. Geological Society of America Today 8: 1-7.

Self, S. 2006. The effects and consequences of very large explosive volcanic erupions. Philosophical Transactions of the Royal Society, Series A, Mathematical, Physical, and Engineering Sciences 364 (1845): 2073-2097. doi: 10.1098/rsta.2006.1814.

SERNAGEOMIN. 2008. Eruption reports of the Servicio Nacional de Geología y Minería. Available at: www. volcano.si.edu/world/volcano.cfm?vnum=1508041\&volpage=weekly (accessed 10/04/2013).

Stern, C.R.; Navarro, X.; Muñoz, J. 2002. Obsidiana gris translúcida del volcán Chaitén en los sitios arqueológicos de Quilo (Isla Grande de Chiloé) y Chanchán (X Región), Chile, y obsidiana del Mioceno in Chiloé. Anales del Instituto de la Patagonia 30: 167-174.

Tuttle, O.F.; Bowen, N.L. 1958. Origin of granite in the light of experimental studies in the system $\mathrm{NaAlSi}_{3} 0_{8}$ $-\mathrm{KAlSi}_{3} \mathrm{O}_{8}-\mathrm{SiO}_{2}-\mathrm{H}_{2} \mathrm{O}$. Geological Society of America Memoir 74: $153 \mathrm{p}$.

Valenzuela, C.E. 2011. Tasa de Crecimiento del complejo de domos del Volcán Chaitén, periodo Mayo 2008 Diciembre 2009. Thesis (Unpublished), Universidad de Chile: $57 \mathrm{p}$.

Watt, S.F.L.; Pyle, D.M.; Mather, T.A.; Martin, R.S.; Matthews, N.E. 2009. Fallout and distribution of volcanic ash over Argentina following the May 2008 explosive eruption of Chaitén, Chile. Journal of Geophysical Research 114 (B04207). doi: 10.1029/2008JB006219

Watt, S.F.L.; Pyle, D.M.; Mather, T.A. 2013. Evidence of mid- to late-Holocene explosive rhyolitic eruptions from Chaitén Volcano, Chile. Andean Geology 40 (2): 216-226.

Wicks, C.; de la Llera, J.C.; Lara, L.E.; Lowenstern, J. 2011. The role of dyking and fault control in the rapid onset of eruption at Chaitén Volcano, Chile. Nature 478: 374-377.

Manuscript received: October 17, 2012; revised/accepted: January 31, 2013; available online: February 01, 2013. 